N. OLLIVIER, T. TOUPY, R. C. HARTKOORN, R. DESMET, J.-C. M. MONBALIU*, O. MELNYK* (UNIVERSITÉ DE LILLE, FRANCE AND UNIVERSITY OF LIÈGE, BELGIUM) Accelerated Microfluidic Native Chemical Ligation at Difficult Amino Acids toward Cyclic Peptides Nat. Commun. 2018, 9, 2847.

\section{Native Chemical Ligation by Microflow Chemistry}

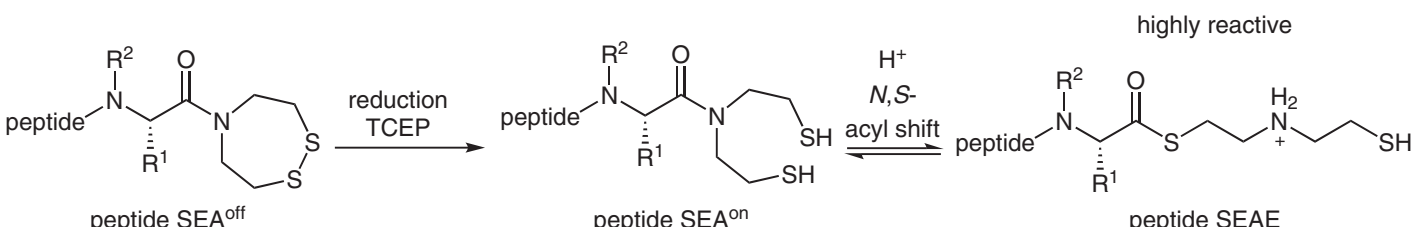

peptide SEA ${ }^{\text {off }}$

peptide SEA ${ }^{\text {on }}$

peptide SEAE

feed solution 1
pPeptide SEA ${ }^{\text {on }}(7 \mathrm{mM})$
TCEP (100 mM), pH 1
CyslleLeuLysGluProValHisGlyVal-SEA ${ }^{\text {on }}$
CyslleLeuLysGluGlyValHisGlyVal-SEA ${ }^{\text {on }}$
CyslleLeuAsnGlyProValHisGlyVal-SEA $^{\text {on }}$
CyslleLeuAspGlyProValHisGlyVal-SEA $^{\text {on }}$
CyslleLeuAsnGlyProValHisGlyLeu-SEA $^{\text {on }}$
CyslleLeuAspGlyProValHisGlyLeu-SEA $^{\text {on }}$
CyslleLeuLysGluGlyValHisGlyThr-SEA $^{\text {on }}$
CyslleLeuLysGluGlyValHisGlylle-SEA $^{\text {on }}$
CyslleLeuLysGluGlyValHisGlyPro-SEA $^{\text {on }}$
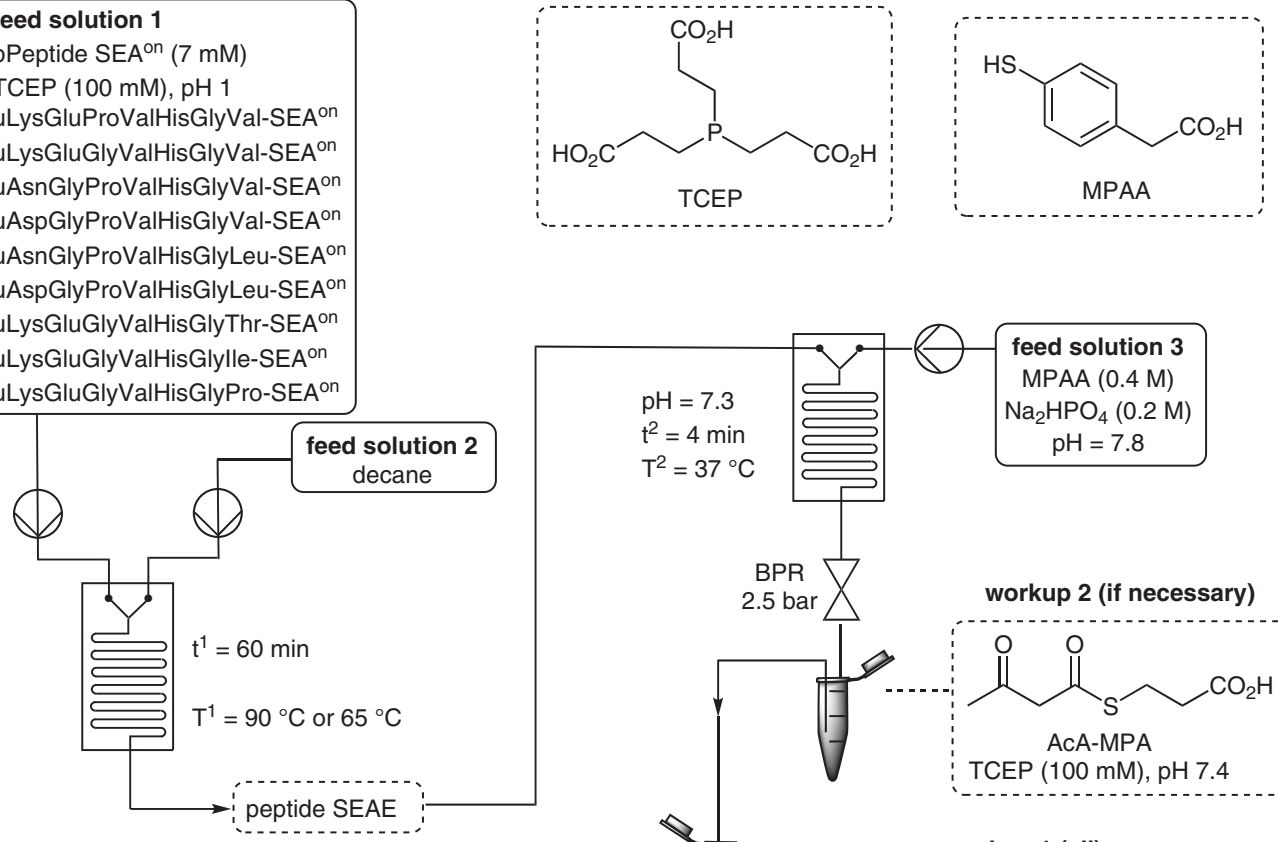

Category

Peptide Chemistry

Key words

native chemical ligation

cyclic peptides

microflow reaction

flow synthesis

thioesters

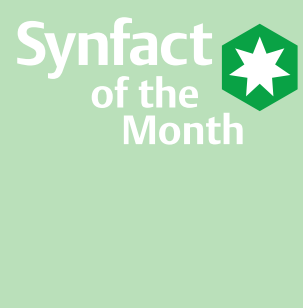

Significance: The authors reported a fast and highly efficient intramolecular cyclization of peptides with native chemical ligation under homogeneous microfluidic conditions, in which the formation of highly active $S$-\{2-[(2-sulfanylethyl)amino]ethyl] peptidyl thioesters is a key step.
Comment: This scale-independent microfluidic native chemical ligation proceeds rapidly, even for difficult junctions, and realizes an expedient preparation of bioactive macrocyclic peptides. 